UDK 811.163.42'344

811.163.42'282“18“"

Izvorni znanstveni rad

Rukopis primljen 2. VII. 2018.

Prihvaćen za tisak 12. XI. 2018.

Ivana Lovrić Jović

https://doi.org/10.31724/rihjj.45.1.7

Institut za hrvatski jezik i jezikoslovlje

Republike Austrije 16, HR-10000 Zagreb

ilovric@ihjj.hr

\title{
FONOLOŠKE ZNAČAJKE JEZIKA DUBROVAČKIH ČESTITARSKIH PJESAMA S POČETKA 19. STOLJEĆA
}

U radu se opisuje fonološka razina jezika kolenda iz 19. stoljeća. Njihov je autor Mato Zamanja, dubrovački vlastelin i potomak Ivana Gundulića. Pisao ih je vrlo mlad i razigran, potpuno odterećen obiteljskoga pjesničkog bremena pa se u njima očekuju elementi pučke parlate razapete $\mathrm{u}$ formalnim metričkim zadanostima. Budući da se dubrovački govor iz kolenda promatra u kontekstu dubrovačkoga idioma tijekom vremena i u raznim književnim i neknjiževnim vrstama, jezične se značajke opisuju i komparativnom metodom kad se uspoređuju s rezultatima jezične analize dubrovačkih oporuka iz 17. i 18. st., dubrovačkih frančezarija (18. st.) i Gundulićeva jezika (17. st.).

\section{Uvod}

Rukopisna zbirka koja na prvoj stranici ima napis Kolende od godišta 1817., 1818., 1819. - u Rijeci sadrži 25 kolenda i prozni uradak naslovljen Testamenat jednoga zubatca, donesen i prolegan na trpezi u g. Mare Đivove na Svetoga Nikolu, a čuva se u Znanstvenoj knjižnici u Dubrovniku. ${ }^{1}$ Osim što je ova građa poslužila za povijesni opis staroga Dubrovnika, zbirka je zanimljiva i stoga što je u njoj sabran repertoar kolenda koje su uglavnom imale ,jednokratnu” porabu što su autori inače rijetko zapisom sačuvali.

Kolendom su Dubrovčani čestitali blagdane Sv. Luke, Sv. Martina, Sv. Nikole te Božić, Novu godinu i Vodokršće. Izvodila se tako što bi jedan kolendar pred vra-

\footnotetext{
1 Njima se, s povijesnoga, etnološkoga i antropološkoga očišta, već pozabavila Obradović Mojaš (2012 i 2017) iz čijega se rada (2012: 389-393) donosi njihov opći opis.
} 
tima rodbine ili prijatelja otpjevao kiticu, a zatim ga je slijedila družba otpjevavši refren. Nakon što bi mu kolendari pjesmom uoči blagdana uputili dobre želje, domaćin bi ih prigodno darivao, najčešće pozivajući ih u svoju kuću na čašćenje.

Kolendarski su stihovi sadržavali prepoznatljive kolendarske formule koje su se, u izmijenjenim oblicima, zadržale do današnjice. Starijim su se ljudima pjevale samo hvale, a mlađima šaljivi i duhoviti stihovi pri čemu se pazilo da se ne prijeđe mjera dobra ukusa.

Premda su u generičkome smislu to pjesme prigodnice, nekolicina pjesnika nadišla je te okvire svojom nadogradnjom u smjeru birane poezije, no umetanjem šaljivih detalja koji su se odnosili na fizičke i duševne osobine dobrih prijatelja, svojte i znanaca, taj se tekst danas može promatrati i kao trag o pučkoj parlati. Upravo su te značajke kolendu svrstale u slobodniju i veseliju vrstu pjesme, a njezin je osobit sadržaj, namjena i prepoznatljiv obiteljski govor učinio zasebnim pjesničkim oblikom. Riječ je o zabavi koja opušta od težine života, razveseljava i intelektualno odterećuje. Pri njihovoj je povijesnoj analizi Obradović Mojaš (2012) utvrdila kako je riječ o djelima pisanima govorenim jezikom, gdješto i makaronštinom - mješavinom hrvatskoga, talijanskoga i latinskoga jezika. Česta pojava prebacivanja jezičnih kodova dodatno ukazuje na želju za neobaveznim rijekom. Kolende se ne oslanjaju ni na tradiciju visokih zabavnih žanrova proširenih u doba renesanse i baroka, iako izdaleka prizivaju komediju i satiru.

Pisao ih je mladi dubrovački plemić Mato Zamanja. Njegova je majka Nika bila kći poznatoga Franatice Sorga (1706. - 1771.), pravnika, prevoditelja i pjesnika, te sestra Pijerka Sorga, pjesnika i dopunitelja Osmana. Pjesnik Ivan Gundulić bio joj je šukundjed.

Svaka kolenda počinje s novim poletom kolendarskoga veselja koje niti interes, niti plata, dovodi na ova vrata. Većina ih je pisana u osmeračkome četverostihu. Iznimka su pripjevi u dvostihu u uvodnome ili završnome dijelu kolende. Karakteristična im je uobičajena kolendarska matrica: dolazak pred vrata, blagdanski zaziv, hvaljenje gospara i njegove obitelji, prizivanje svakoga dobra na odabrani dvor (široki ulaz u kuću) i najposlije - čašćenje kolendarske družine uz (uobičajenu) ponovljenu čestitku.

Jezična studija Zamanjinih kolenda upotpunjuje moja prethodna istraživanja ponukana donedavnom prazninom u istraženosti dubrovačkoga govora iz razdo- 
blja 17. i 18. stoljeća. ${ }^{2}$ Osim toga, opis govora iz kolenda čini rijetku znanstvenu obavijest o dubrovačkome govoru iz 19. stoljeća, s obzirom na to da je jedinu ponudio Luko Budmani prije 135 godina, u neveliku, ali vrijednu radu o dubrovačkome govoru svojega vremena (Budmani 1883).

Žanrovska pripadnost tih kolenda od velike je važnosti pri tumačenju značajka koje će se detaljnije promatrati. Kolende pripadaju pjesničkomu izrazu pa se neke jezične značajke očekuju, no one se sadržajem i ulogom uvelike razlikuju od visokoga pjesničkog stila, što ih čini analitički izazovnima. Moglo bi se reći da se u kolendama više nego u drugim pjesničkim vrstama očekuje bilo puka, što znači da u njihov jezik prodire i pučka parlata. Valja ovdje naglasiti i to kako je Mato Zamanja svoje kolende počeo pisati u adolescentskoj dobi, pa je možda i buntovnost toga životnog razdoblja bila bitnim činiteljem njegova odmaka od pjesničke tradicije visokoga stila što ju je baštinila njegova obitelj.

Rezultati ove analize uglavnom će se omjeravati o one dobivene analizom dubrovačkih oporuka iz 17. i 18. stoljeća, kadšto i o Gundulićev jezik, kao i o jezik dubrovačkih frančezarija. ${ }^{3}$ Zato valja reći koju i o jeziku spomenutih korpusa.

Oporuka je osobni i strogo formalni akt. Čini je tekst kojim oporučitelj ostavlja svoju imovinu imenujući nasljednike. Karakteriziraju je jezične formule na početku i na kraju teksta, dok je središnji dio razgovornijega tipa i odterećen formalnih zadatosti. Riječ je o staloženim izričajima, izdiktiranima u stereotipnome obliku bliskomu prijatelju, bilježniku, ili prepisivanima u Notarijatu, a katkad su oporučitelji pisali i vlastitom rukom. Nalaze se u dubrovačkome Arhivu, u seriji Testamenta Notariae (10,1.). Svaka oporuka sadrži izjavu o točnome vremenu, mjestu i okolnostima nastanka te proglašenje o punovaljanosti. Bilo da su oporuke napisane vlastoručno (olografske) ili tuđom rukom (alografske), svjedoci su obavezni (jedan je nedostatan). Većinu oporuka pišu ljudi neskro-

\footnotetext{
2 Autorica je znanstveni interes usredotočila na istraživanja onoga dijela jezičnoga korpusa u kojemu se može pronaći trag o razgovornome dubrovačkom idiomu iz prošlosti, tj. pučkoj parlati. Zato je dosad istražila jezik dubrovačkih frančezarija (18. st.) i jezik dubrovačkih oporuka pisanih hrvatskim jezikom iz 17. i 18. stoljeća. To je objavila u dvjema jezičnim monografijama (Lovrić Jović 2014, 2015). Suvremenoga se pučkog govora dotaknula u radu Lovrić Jović i Maslek (2004) te u referatu Je li ljubav važna ako nije amor, predstavljenome na Četvrtoj kroatološkoj konferenciji Dubrovnik u hrvatskoj povijesti, održanoj u ljetnikovcu Bunić - Kaboga (16. 11. 2015. - 18. 11. 2015). Dubrovački govor do toga razdoblja detaljno je istražio Milan Rešatar (1933, 1936, 1941, 1951, 1952)

3 Radi uštede prostora i bolje prohodnosti teksta, pri usporedbi s navedenim istraživanjima neće se navoditi podatak o mjestu u knjizi. Riječ je o već spomenutim jezičnim monografijama Lovrić Jović 2014 i 2015 te Rešetar 1941.
} 
mna imetka. Upravo činjenica da bogatiji slojevi pišu na materinskome jeziku ide u prilog tezi da su Dubrovčani govorili narodnim jezikom. Jer, iako je jezik trgovačkih bratovština bio talijanski, tj. trgovački jezik Sredozemlja, članovi tih bratovština svoju su posljednju volju izricali narodnim, hrvatskim jezikom (Lovrić Jović 2015: 16-18).

Dubrovačke su frančezarije prilagodbe Molièrevih komedija iz 17. stoljeća. Nastaju početkom 18. st. preduhitrivši čak i prijevode geografski i kulturološki bližega Mlečanina Carla Goldonija (1707. - 1793.). Razlog tomu nalazi se u nužnosti veselja i smijeha na narodnome jeziku jer se Dubrovčanima tada nudila samo pučka komedija na talijanskome jeziku i u izvedbi pučkih talijanskih družina. I književnost na narodnome jeziku u osvitu 18. stoljeća bila je vrlo oskudna. Potres iz 1667. godine uzdrmao je i njezine već dobro uspostavljene temelje (Gundulićev mu i Držićev opus prethode). Obrazlažući povod stvaranja frančezarija u Dubrovniku, tj. značaj i Molièreovu ulogu u spašavanju ,ugrožene narodne riječi na dubrovačkoj pozornici”, filolog romanist Mirko Deanović zaključio je: „Da nije bilo Molièreova repertoara, narodni bi jezik bio jamačno zamro na dubrovačkim daskama gotovo pola vijeka ranije” (Deanović 1972: 10-11). Frančezarije su dobar jezični korpus za trag o pučkoj parlati zato što se iz izvanjezičnih datosti, ali i po unutarjezičnoj analizi, razumijeva kako su frančezaristi pisali za puk, a stoga i na pučkome idiomu. U oskudici dijalektoloških tekstova iz toga razdoblja, frančezarije su dobar ogled stiliziranoga pučkog govora starih Dubrovčana (Lovrić Jović 2014: 10-16). Budući da je riječ o preradbama, a ne o prijevodima, francuskomu je predlošku dana sasvim nova boja, umetnute su domaće riječi, izrazi i folklor, dodane se neke nove usporedbe i slike, metafore i hiperbole, komična ponavljanja riječi, krilatice, narodne izreke, usklici itd., čime se postižu veći komični efekti. Likovi koji progovaraju tim dubrovačkim govorom u jezičnome su smislu vrlo iznijansirani, pa tako ljubovnici govore ishitrenim i afektiranim jezikom ljubavne poezije, dok je mnogolikost i mnogostrukost romanizama obilježje vlastelinska govora, sasvim različita od govora seljaka iz okolice, djetića i djevojaka „sasvijem iza brda” koji govore „sočnim svakidašnjim načinom izražavanja" punim turcizama. Peraštani svoj izričaj kite mletačkim elementima, a Talijani se služe makaronskim jezikom. Sve to frančezarije svrstava u domaću, a ne u prijevodnu književnost.

Kako bi se jezične značajke kolenda bolje razumjele i lakše tumačile, u analizi je važno istaknuti po čemu se razlikuju od jezika oporučitelja, frančezarista $i$ 
Gundulićeva izričaja. Pritom valja uzeti u obzir da je svaki od tih triju korpusa mnogostruko opsežniji od korpusa kolenda pa (nisku ili visoku) čestotnost pojedinih fonoloških elemenata treba razmatrati s relativnom vrijednošću. ${ }^{4}$

U historijskim je fonološkim istraživanjima hrvatskoga jezika, odnosno u dijalektološkim proučavanjima, odraz praslavenskoga vokala ě od najveće važnosti jer sačinjava osnovnu i lako uočljivu razliku među novoštokavskim govorima (ijekavski izgovor nasuprot ikavskomu). Kako je današnji standardni jezik samo jedan od ostvaraja novoštokavštine, važno je vidjeti kakav je bio dubrovački govor kolende iz 18. st., uzimajući u obzir njezine gore spomenute jezične i izvanjezične odrednice. Naravno, dijalektološka će se opredijeljenost iščitavati i iz ostalih fonetsko-fonoloških značajka.

S obzirom na slovopis oporuka teško je utvrditi kvantitetu sloga s jatom. Ukoliko nije u pitanju ikavski ili ekavski odraz, na tome se mjestu u rukopisu redovito nalazi ie. Ono je transkribirano prema suvremenim transkripcijskim načelima, odnosno u skladu s današnjom pravopisnom normom standardnoga jezika (ije/je).

U ovoj se studiji neće istražiti jednačenje suglasnika po zvučnosti i po mjestu tvorbe jer korpus takvo što ne može potvrditi sa sigurnošću. Jednačenje se u promatranome razdoblju možebitno provodilo više nego što to može biti vidljivo u tekstu jer ono, dijakronijski gledano, u samome postupku provođenja spomenutih jednačenja zahtijeva i razriješena pravopisna pitanja. Ona u promatranome razdoblju vjerojatno nisu bila ni postavljena, pa ni riješena.

\section{Odraz jata}

U osnovama je potvrđen (i)jekavski, ikavski i ekavski odraz.

Ijekavski su odraz potvrdili sljedeći primjeri - cěl-: cijela; cěn-: cijeni, cijenite; ěd: izjestit, jeli, objeda, jeda (G jd. 'jed'); děl-: djela, djelim (I mn. 'djelo'), nedjelju; děli(ti)-: udijelio, udijeljena, razdijeliti; dvě-: dvije; gdě-: gdje; lěp-: lijepe, lijepa, lijepo, lijepu; lět-: ljeto, ljeta; lěv-: zalijevat se; měst-: mjesto; pěsn-:

\footnotetext{
4 Podatci za fonološku analizu pripremljeni su ekscerpiranjem primjera, a u samoj je analizi primijenjen analitičko-deskriptivni pristup te induktivno-deduktivna metoda i metoda sinteze u obradbi podataka i izvođenju zaključaka. Budući da se dubrovački govor iz kolenda promatra u kontekstu dubrovačkoga idioma tijekom vremena i u raznim književnim i neknjiževnim vrstama, primijenjena je i komparativna metoda.
} 
pjesni; pěv(a)-: pjesni, pijevac, pjevat, pjevo; prě-: prije, najprije; ${ }^{5}$ prět-: prijeti; rě(ti)-: rijet, izrijeti, riječi; rěk-: Rijeci, Riječanima, riječko, riječki; sěd-: posje$d u$; slěd-: slijediti, slijedi; spě-: dospjet, dospjela, dospjelo; svědok-: svjedočiti, svjedoče; svět-: svijetu, svijeti (L jd. 'svijet'); svět(I)-: svijetlo, prisvijetla, svijeće; ulěz(ti)-: uljeziti, uljeze, uljegoše, uljeste; umě(ti)-: umijem, umijemo; vědě-: pripovijes; věr-: vjerovat, vjerna, vjerne; vĕtr-: vjetra.

Ikavski je odraz potvrđen u sljedećim primjerima: ovdě-: ovdi; dolě-: doli; gorě-: gori i prěk-: priko. Prefiks prě- također je potvrđen ikavskim refleksom: priblagom, pridragom, prisvjetla, pridaj, pridaš, pridano. Jednako je zabilježeno u oporukama i u frančezarijama, s iznimkom rijetkoga jekavskog lika ovdje iz oporuka.

Ekavski odraz (ně-) potvrđen je u neodređenoj zamjenici neki, neke - koja se u drugim dvama korpusima s mnogo većom čestotnošću pojavljuje s jekavskim odrazom (njeka, njeki, nješta, nješto, njekoliko, njeki, njeka, njekoliko itd.).

Mješoviti je odraz u kolendama potvrđen samo u dvjema osnovama: prěd-: a) naprijeda, unaprijeda; b) prid, i trěb-: a) trijeba (imenica); b) treba (imenica). U oporukama i u frančezarijama ta je pojava potvrđena mnogostruko - oporuke: cijelo/cile; gdje/gdi; razdijeli/dila; djecaldica; dvjesti/dvisti/dvesta; promjenu/minjam; najprije/najpri; njekoliko/nekoliko; pjevaju/pivana; posljednji/najposlednji; svjedočba/svidodžbom/svedočim; tijelaltilo/telesne; ${ }^{6}$ vijeke/navik; vjeru/viru. Frančezarije potvrđuju također više primjera: čovjek/čovik; ovdjelovdilovde; mjerio/lizimirstvo ('licemjerstvo'); najposlije/dosle; slijedit/najposlednji; vavijek/vik.

Ikavski je odraz kadšto pozicijski uvjetovan pa ne pripada pravim ikavizmima: cĕl > cio, děl- > dio.

Nakon pokrivenoga $r$, odnosno glasa $r$ kojemu prethodi suglasnik iza kojega nije morfemska granica, u kolendama je potvrđen ekavski ostvaraj jata: breme, treska, tresku, treskom; sreće, sreću, srećna. Iznimku čini imenica trijeba, kao lik koji je obilježio jezične korpuse starijega dubrovačkog govora. Slično je u usporednim korpusima, oba su korpusa u toj poziciji pokazala mješoviti odraz, tj. jekavski i (u većini slučajeva) ekavski: frančezarije: krepos, srećan; grjehova-

${ }_{5} \mathrm{~S}$ obzirom na likove prije/pri/pre - tzv. jekavske, ikavske i ekavske odraze jata, navedene primjere promatramo u ovoj skupini odraza. Valja stoga napomenuti kako je zapravo u liku prije samo glas $i$ odraz jata, dok je -je zapravo nastavak koji u ekavskoj i ikavskoj inačici otpada. Primjer bi se prije tada mogao držati likom s ikavskim odrazom jata i postojećim nastavkom što se nalazi u jekavskim govorima.

6 Ekavski je odraz u liku telesne očekivan jer je to dubrovački knjiški ekavizam. 
$l i$, uvrjeda, trijeba; oporuke: krepos/vrjeća. U oba usporedna korpusa pojava je provedena načelno, tj. uvijek u istim leksemima pa oporučitelji uvijek pišu sreća, sreću, ali vrjeća, a nikad vreća. Frančezaristi ispisuju krepost, kreposti, kreposna (nikad krjepost itd.), odnosno redovito grjehovali, grjehuju (nikad grehovali itd.).

Prezentu glagola 'biti’ niječni je oblik beziznimno ijekavski ije: nijesi, nijesmo, nijesu. Jednako je i u frančezarijama, dok je u oporukama pronađena i jedna rijetka iznimka (nisu).

U imeničkih je riječi zabilježena dubrovačka crta u gramatičkim morfemima koji dolaze nakon osnove koja završava na jedan ě. Ti su oblici stari lokativi množine -ěh osnova na $o$, te instrumentala jednine i genitiva, dativa, instrumentala i lokativa na -ěm, -ěh, -emi u zamjenica i pridjeva. U staroslavenskome su jeziku to bili nastavci tvrdih osnova, dok meke osnove imaju $i$ namjesto $\check{e}$. Tako glas $i$ u tome položaju i nije odraz, nego primarni glas. Kasnije su se jedni i drugi nastavci pomiješali i izjednačili, pa se, na koncu, za obje osnove bez razlike uzimaju ili nastavci mekih ili tvrdih osnova. U dubrovačkome su govoru prevladale potonje i za meke osnove: tijeh, mojijeh. Pođe li se od pretpostavke da je ijekavizam u gramatičkim morfemima opći pokazatelj ijekavizma, primjeri što slijede svjedoče o čistome ijekavskom usmjerenju dubrovačkoga idioma.

Ta se značajka u kolendama, s tek jednom iznimkom u smjeru standarda (njih), potvrđuje u zamjenično-pridjevnome morfemu: svijeh, ovijeh, tijeh, kijem (I jd. od čakavskoga oblika ki), dugijem, pridragijem, svijem, priganijeh, dumanjskijeh, dubrovačkijeh, kućnijeh, takijeh, zdravijeh; i u brojeva: drugijeh, jednijem, drugijem.

Ista je značajka potvrđena i u liku svakijer, koji potvrđuje i navezak -r.

Lik ovi u dubrovačkome govoru stoji za zamjenicu ovaj pa je potvrđen i u kolendama, a tako i lokativ jednine s ijekavskim morfemom: ovijem (ko u dvoru ovijem pribiva).

Jednako su potvrdili i usporedni korpusi (oporuke i frančezarije) gdje je iznimaka otprilike jednak broj.

Imperfektivni glagoli potvrđuju ikavski i jekavski odraz: činit, živio; odnosno: življet ${ }^{7}$ viđet, viđela. Potonja su dva primjera ishod jekavske jotacije bez koje bi glasili vidjet i vidjela.

Prijelaz $j>l j$ promatra se u dijelu o palatalizaciji, odnosno depalatalizaciji suglasnika. 
Dočetno $-l$, koje će se promotriti i napose, u kontekstu odraza jata potvrđuje vokalizaciju. Kad je na kraju sloga ili riječi, suglasnik - $l$ se vokalizira, a glas $\breve{e}$ odražava se ikavskim ostvarajem. U kolendama to potvrđuju sljedeći primjeri: (glagolski pridjevi radni) izio, ćio, udijelio, bio, potvrdio, živio, rodio, čudio, zakupio, (pridjev) cio i (imenica) dio. Frančezarije su potvrdile isto (dio, udionici; htio, hotio, donio, vidio, izio, pripovidio, sio, smio, umio, živio, žudio; smion), a tako i oporuke (prid. bio; hotio, donio, obudovio; dio, udionica).

Hiperjekavizaciju, koja je u dubrovačkome govoru ovjerena u dočetku imeničnih riječi -ir, kolende su potvrdile u liku pastijerica. Prošireni dočetak u imeničnim riječima nalazi se i u oporukama (manastijer i štogodijer) i u frančezarijama (pastijer i manastijer).

Sekundarni ě u primljenicama promatra se odvojeno.

U kolendama je potvrđen jedan takav primjer, to je leksem lijerica u kojemu se naglašeni vokal $i$ iz talijanskoga lira proširio u ije. Po istome je hiperijekavizmu poznat i stari iz književnosti poznati leksem lijer za 'ljiljan' u kojemu se potvrđuje ista promjena jer je u latinskome glasio lilium, a u grčkome lirion. S obzirom na opseg korpusa ne začuđuje da su oporuke potvrdile znatno veći broj primjera za ovu pojavu: bekjer $<$ tal. beccheria, kandjela $<$ tal. candela, skudjela $<$ venet. scodela, paramijenta $<$ lat. paramentum, rom(i)jenča $<$ tal. rame; mjentovati $<$ tal. mentovare; imena Mandalijena < lat. Magdalena i Stjepan < lat. Stephanus te prezime Lovrijenčević $<$ tal. Lorenzo, lat. osn. laure). Jednako je i u frančezarijama: bjestimija $<$ tal. bestemia, bjestimat $<$ tal. bestemiare, kaštjele $(\mathrm{N}$ jd.: kaštio*) $<$ tal. castello; talijer $<$ tal. tallero; Žudjelu $(\mathrm{N}$ jd.: Žudio $)<$ tal. giudeo, barjela $(\mathrm{N}$ jd.: bario*$^{*}<$ tal. barile, kunijelj $<$ tal. coniglio. Frančezarije su potvrdile i lijer.

\section{Dočetno $-l$ i glas $h$}

Suglasnik - $l$ na kraju riječi ili sloga prelazi u samoglasnik - $o$. Tu pojavu kolende potvrđuju u glagolskome pridjevu radnom: izio, ćio, udijelio, bio, potvrdio, živio, rodio, čudio, zakupio; u pridjevu cio, veseo i u imenici dio. Posredno je vokalizacija potvrđena i u nizu primjera koji odražavaju jezičnu promjenu sažimanja dočetnoga $a o>o$ (pjeval $>$ pjevao $>$ pjevo) i tu je ona također beziznimna (primjeri slijede niže u odlomku o sažimanju dočetnoga $a o$ ). 
Beziznimna potvrđenost spomenute pojave u kolendama potkrepljuje Rešetarove tvrdnje da je vokalizacija dočetnoga $-l$ (ako nije postponirano glasu $r$ ) prvo provedena u narodnome govoru (Rešetar 1952: 49). To je i pokazatelj već prije uočena Zamanjina stila koji narodsku komponentu izdiže iznad poetske čime se autor, namjerno ili ne, ograđuje od visokoga stila svojih dičnih predaka, poglavito Ivana Gundulića. ${ }^{8}$

Pojavljivanje glasa $h$ gotovo je identično današnjemu. U kolendama je rijetko potvrđeno njegovo otpadanje, samo u obliku aorista glagola 'biti' u prvome licu: $b i$, dok je u ostalim slučajevima ovjerena njegova stabilnost, tj. potvrđeni su cjeloviti likovi. Glas $h$ na početku riječi vidljiv je u primjerima: haljine, hvale, hvala, hodeć, hita, uhititi, hitajuć, hoćemo, homo (uzvik 'hajmo'), hobotnice, hitrinom, hladne, hitre. U sredini riječi etimološko se $h$ nalazi u primjerima: (imenice) mahnica (G jd. od 'mahnitac'), svrhe, kruha, straha, trbuha, Mihu, Mihajla; (pridjevi) mahniti, suha, skuhana, oholi; (zamjenica) njihove; (glagoli) dohode, iznahodit, pohodit, prohodite. Na kraju riječi zabilježeno je redovito u fleksijskim završetcima (svijeh, ovijeh, tijeh, priganijeh, dubrovačkijeh, kućnijeh, takijeh, zdravijeh, dumanjskijeh; drugijeh) te u oblicima aorista glagola 'biti': bih, rekoh, ćeh ('htjeti'). Glagol htjeti u svim pronađenim primjerima zadržava glas h: hoću, hoće, a jednako tako i glagol hoditi u imperativu - hote.

Glas $h$ ne izostaje ni kad je anteponiran glasu $r$ : hrane, dohraniti.

Glas $h$ nalazi se u dočetnome položaju u prilogu 'lani': lanih. ${ }^{9}$

Zamijenjen je glasom $k$ kad je anteponiran glasu $t$ : ktjela.

Glas $h$ u službi duljine nije potvrđen.

Oporuke i frančezarije pokazale su sličnu situaciju, uz iznimku kojom oporuke potvrđuju $h$ kao znak dužine (haljinah), a istim leksemom frančezarije svjedoče o otpadanju početnoga $h$ - (aljine), no kao znakovitu i izdvojenu iznimku što čini ruralni idiom lika - kmeta Matka.

Sekundarno se $h$ u riječima s početnim $r$ - u kolendama ne pojavljuje što pokazuju primjeri rđavo i rđava. Istim su leksemom pojavu osvjedočile frančezarije (rđa, rđav, rđavo) i oporuke (rđav).

\footnotetext{
Gundulić za 'bijel' nema bio, već bil.

9 ARj (5: 898) navodi da se oblik lanih pronalazi u Crnoj Gori.
} 
U svojemu primarnom liku ostaje i skupina $h v$ (hvala, hvale). O tome da je glas $f$ na tome mjestu tek recentnija pojava u dubrovačkome govoru svjedoče i oporuke i frančezarije. Prve imaju češće hvala, a iznimniji su primjeri tipa prifatio, dok u frančezarijama, dakle u ogledu dubrovačkoga govora 18. stoljeća, skupina $h v$ redovito prelazi u $f$ samo onda kad se primjer nalazi u dramskoj dionici Bosanaca (Ilije i Vukašina): fatam, fata, ufatih, prefatio, zafalit itd. U govoru dubrovačkih likova $h v$ ne prelazi u $f$ : pohvalit, zahvalit, uzhvališ, zahvaljivam itd.

\section{Jotacija}

Praslavenska jotacija nije potvrđena u prijedlogu 'među' koji se uvijek pojavljuje sa štokavskim odrazom: među, a likovi meu ili meju, tipični za dubrovački književni, posebno pjesnički jezik, nisu potvrđeni.

Pridjev rđav pojavljuje se samo jednom, sa štokavskim odrazom.

Štokavsku jotaciju potvrđuju i imenice 'gvožđe': gožđa, gozđa i 'grožđe': grožđe, grozđa. Imenica 'gospođa' u kolendama je potvrđena dvojako - s provedenom štokavskom jotacijom: gospođa, gospođe i s likom koji je ne ovjerava: gospoja, gospoje. Oporuke i frančezarije nisu zasvjedočile likom gospoj-. Premda Rešetar (1952: 47) za čakavski lik gospoja tvrdi da je, osim u književnosti, prisutan i u govoru, njegovu je potvrđenost u kolendama bolje tumačiti pjesničkim elementom.

Prilog 'također' ili pridjev 'tuđe' u kolendama nije potvrđen, no nekoliko se puta pojavljuje jotirani lik sveđ, slično kao i u oporukama (uglavnom također, tuđijeh, sveđer, sveđ, a iznimno takojer).

Imenica 'plaća' u kolendama je beziznimno potvrđena s nejotiranim likom: plata, platu, jednako kao u usporednim korpusima.

Pridjev 'sretan', naprotiv, ovjeren je uvijek s jotiranom osnovom srećna jednako kao i u frančezarijama, dok za oporuke nije pronađen taj leksem.

U slučajevima u kojima je u osnovi glas $d$ proziran, jotacija je provedena sa štokavskim odrazom: građane.

Praslavenska je jotacija provedena i u imenici nemoć. 
Skupovi *stj i *skj beziznimno imaju odraz št: u osnovi - štetu, proštenja; u sufiksu - godište, godišta; u oblicima glagola ‘štovati’ - štuje i iskati - ištu; u prilogu 'jošte' - jošter, u oblicima imperfektivnih glagola: propuštiva.

Jotacija je potvrđena u izvedenica glagola na -iti - u infinitivima: doći, moć, poći, te u ličnim glagolskim oblicima: pođe, dođe. Uz takve imamo i likove u kojima ona nije provedena: infinitivi otiti, iziti te lični oblici obide, otide, izidite, izidete.

Lik apstraktne imenica izvedene sufiksom -6je - zdravlja - također potvrđuje sekundarnu jotaciju.

Jekavsku je jotaciju ovjerio glagolski pridjev radni od 'htjeti' i 'letjeti': ćio, ćela, ćeli, dolećeli, aorist ćeh ('htjedoh, htijah'), infinitiv viđeti, lećeti, glagolski pridjev trpni provrćene te imenica đevojka i imenica crnjela čiji kanonski oblik crnjel potvrđuje ARj (1: 848) smještajući ga, kao ime ribe, upravo u Dubrovnik. Ista pojava nije potvrđena u liku imenice 'nedjelja': nedjelju.

Trima je inačicama ostvaren prilog 'gdje': gdje, dje i đe.

Dva su usporedna korpusa potvrdila gornje značajke, s nešto razlika. U frančezarijama su potvrđeni likovi onđe i ovđe, no oni pripadaju dramskomu liku Bosanca. Dok su u dubrovačkim oporukama iz 17. i 18. st. primjeri s provedenom jekavskom jotacijom činili pravu iznimku, u frančezarijama oni nisu rijetkost. Tako su neodređene zamjenice s osnovom ne- redovito ovjerene s jotiranim likom, dok prilog s osnovom dě- jasno razdvaja dva govorna područja: dubrovačko zaleđe, u kojemu se jotacija provodila - đe, i sam grad Dubrovnik, s neprovedenom jotacijom - dje. U dubrovačkim oporukama iz istoga razdoblja nijednom nije ovjeren primjer toga tipa s jotiranim likom (iako su mnogi oporučitelji bili iz okolice).

Analoška je jotacija u frančezarijama protumačena kao značajka kmetovskoga (težačkoga) i bosanskoga govora (iđem, iđeš, iđe, iđemo, iđu; imp. iđi). Glagolski se lik viđeti tamo nije ovjerio, već samo njegova nejotirana inačica (vidjeti), što nije, pak, slučaj u oporukama, gdje se jednakom čestotnošću pojavljuju obje inačice, neovisno o različitim oporučiteljima i tijekom cijeloga promatranog razdoblja. Razdoblje nakon frančezarija, 19. stoljeće, obilježila je i glasovna promjena kojom suglasnik $d+j$ iz kratkoga odraza $\check{e}$ prelazi u $d$ pa su osvjedočeni i likovi đed, đevojka, viđet i neđelja. Uz njih će se još zadržati i stariji likovi djed, djevojka i letjeti, pogotovo i beziznimno u Cavtatu (Budmani 1883: 157). 


\section{Druga palatalizacija (sibilarizacija)}

Primjeri koji bi mogli potvrditi sibilarizaciju u kolendama nisu je ovjerili: $d r u g i$, drugijeh, drugijem; dubrovačke, dubrovačkijeh, riječki, riječka što je u skladu s normom standardnoga jezika, no dubrovački je govor za ranije razdoblje, na primjer u oporukama, potvrdio i likove s provedenom sibilarizacijom: druzijem, ubozijem, velicijeh, dok Rešetar (1952: 51) isto pronalazi i u pridjevnim završetcima -ski i -čki: dubrovačci.

Kolende tu glasovnu pojavu nisu potvrdile ni u imenici 'vika' - viki, koja se u standardu pojavljuje s provedenom sibilarizacijom.

\section{Razjednačivanje suglasnika}

Razjednačivanje suglasničke skupine $m n j>m l j$ korpus je potvrdio imenicom 'pomnja' - pomljom i prilogom pomljivo. U oporukama se nalazi s dvojnim likovima: pomlju i pomnju.

Prijelaz suglasničke skupine $m n>v n$ u korpusu nije ovjeren. Osnova dumnovjerena je u prilogu dumanjskijeh. Jednako su potvrdile i oporuke (dumnam, dumni, dumnica, duman(s)kom) i frančezarije (dumnu). U kolendama je, međutim, ovjerena obratna pojava - prilog 'odavna' potvrđen je likom odamna, a pridjev 'slavni' likom slamni.

\section{Redukcija suglasničkih skupina i gubljenje suglasnika}

U dubrovačkome govoru na početku riječi kadšto ispada (eksplozivni) suglasnik. Kolende su to potvrdile imenicom imenice 'ptica, ptić': tice, tića te imenicom 'kći': ćerca.

Početna skupina $p t$ - nije ovjerena ni drugdje u korpusu, a ostali slični primjeri s mogućim eksplozivnim suglasnikom taj su suglasnik zanijekali.

Zato upitno-odnosna zamjenica 'tko' u korpusu redovito glasi ko, a tako i niko, te nema potvrđene inačice u smjeru standarda ( $t k o$ i nitko), što je u frančezarijama i oporukama slučaj (u potonjima čak i nitkomu). 
U sredini riječi pojava je beziznimno potvrđena u visokočestotnome vezniku 'dakle' koji se pojavljuje u reduciranome liku dake. Pojava reduciranih suglasničkih skupina u sredini riječi obilježila je i Gundulićev jezik (desposki, ljustvo...), a potvrđuju je i oba usporedna korpusa.

Nalaze li se u dočetku riječi, suglasničke se skupine -st i -zd najčešće reduciraju $\mathrm{u}-s,-d$, što je važna dubrovačka značajka do današnjih dana. U kolendama to potvrđuje lični oblik glagola 'biti': jes, te imenice: staros, pripovijes, obilnos, dok potpuno izostaju primjeri s potpunim dočetkom. Frančezarije su otpadanje suglasnika potvrdile obilnije nego cjelovite suglasničke skupine, a oporuke upravo obrnuto pa uz čestotnije likove poput bolest, Isukrst, harnost, krst, šest, živost te glagol jest imaju i rjeđe primjere obratne pojave (duševnos, jakos, koris, krepos, krs, glagol jes). Reducirani je dočetak obilježio i Gundulićev pjesnički jezik, ali i dubrovački govor devetnaestoga stoljeća pa Budmani (1883: 159) nabraja primjere prs, rados, pūs i plaš.

Cjeloviti je dočetak u kolendama potvrđen samo u imenici list.

Početni suglasnik redovito otpada u vezniku 'jer': er, erbo.

U imenici 'gvožđe' gubi se suglasnik v: gožđa.

Redukcija je u kolendama ovjerena i u likovima pridjeva: taku, take, takijeh; te u liku priloga: ovakomu.

\section{Gubljenje i sažimanje samoglasnika}

U dočetku riječi sažimanje skupine $a o>o$ u kolendama je ovjereno redovito: reko, oteko, pjevo, mogo, pomogo. Cjeloviti dočetak nije potvrđen. Ta značajka ne govori nužno o narodskome elementu u jeziku kolenda jer je ona potvrđena i u Gundulićevu pjesničkome jeziku. U oporukama je sažeti dočetak bio iznimkom pa se glagolski pridjev radni čak 23 puta ostvario s punim nastavkom (pisao), dok je samo 4 puta ovjeren sa sažetim likovima (poslo). Pronađen je i primjer u kojemu su u jednoj rečenici ovjereni likovi sa sažetom i likovi s nesažetom završnom skupinom: što je gospar kančilijer upiso i paka prid nami prolegao - što najbolje zrcali nesigurnu porabu po tom pitanju. U frančezarijama je pronađena obratna situacija, tj. prevlast likova sa sažetim dočetkom. U današnjemu 
se govoru nalaze i jedni i drugi likovi, no Dubrovčani nesažetu skupinu doživljavaju kao standardnojezičnu inačicu, dok se za sažeti dočetak odlučuju žele li zazvučati autohtono.

Okrnjeni je infinitiv u kolendama česta pojava: bit, pjevat, tamnjet, naučit, valjat, iznijet, rijet, viđet, oprovat, otvorit, izgovorit, otvorit, umorit, prostit itd., no uz takve primjere potvrđeni su i oni s cjelovitim infinitivom: razglasiti, raksriti, napojiti, činiti, biti itd. Da tomu razlog nije tek metrička potreba, već uobičajena jezična navika, potvrđuju i dubrovačke oporuke iz 17. i 18. stoljeća gdje se cjeloviti infinitiv izmjenjuje s okrnjenim, dok je u frančezarijama (18. st.) reducirani infinitiv redovita pojava, a rijetke su iznimke pronađene samo u stihu zbog potrebe deveterca (koji se gdješto pojavljuje kroz dramski tekst).

Prilog 'tako' u kolendama se dvaput pojavljuje s reduciranim dočetnim samoglasnikom: tak, što se može tumačiti metričkim zahtjevima jer bi u protivnome stih imao deset slogova što nijedan drugi u kolendama nema.

\section{Pokretni suglasnici i samoglasnici}

U kolendama je najčešće potvrđeno dometnuto $-r$ na kraju priloga i veznika: jošter, kader, ter, svudar, svakijer.

Vremenski prilog 'jučer' potvrđen je s likom jučera, a 'onomad' s likom onomadne.

Instrumentalni je oblik zamjenice u 2. 1. jednine ovjeren s naveskom -e: tobome. Vremenski prilog 'večeras' potvrđen je s naveskom -ke što je za vremenske priloge često potvrđeno i u dubrovačkim frančezarijama (danaske, jutroske, večeraske).

\section{Specifične dubrovačke značajke}

Promjena suglasnika $l j \mathrm{u} j$ u Zamanjinim kolendama nije ovjerena: $z$ dravlja, ključe, crevlje, volje, prosuljice, polju, bolje, pozdravlja, spravlja, valja, valjalo (g1.), prijatelja, prijatelje, veselja. U oporučnim tekstovima ta je promjena ni- 
ske čestotnosti (ostavjam, zemje), a češće je zadržavanje glasa lj (bolje, čeljad, volja, ostavljam, koji je najčestotniji glagol u korpusu). Prijelaz lj u $j$ ni danas nije obilježje gradskoga govora, a za 19. je stoljeće Budmani (1883: 157) o tome zapisao: Neki, ali samo manji broj, koji nepomnjivo izgovaraju, ne razlikuju lj od j, i govore boje, uje, mjesto bolje, ulje.

Obratna je promjena, palatalizacija suglasnika $l$, ovjerena u likovima življet i brljog (u oporukama također življet).

Poznati adrijatizam, prijelaz dočetnoga $-m \mathrm{u}-n \mathrm{u}$ kolendama je ovjeren jednom - strašin, a brojniji su primjeri gdje je ta promjena izostala: dum, vranom, damižanom, nogom, mukom, ovom, te glagolski oblici: sam, strašim. Isto su pokazale i oporuke gdje je jedinom iznimkom bio lik dun što se protumačilo činjenicom da taj leksem i nije najbolji primjer za opis ove pojave jer je riječ o primljenici koja u talijanskome jeziku završava na $-n$ : don. U 19. je stoljeću pojava uzela maha pa je Budmani (1883: 158) zabilježio i likove gledan, osan, rukon te pojavu popratio riječima da će za takvim fonološkim izborom posegnuti samo oni koji nepomnjivo govore.

Dočetno je -ć iz okrnjenoga infinitiva zamijenjeno suglasnikom -j: za iznaj te $u$ ovom strani.

Infinitiv s podvostručenim dočetkom dubrovačka je morfonološka značajka ovjerena i u kolendama: pastit. Ista je značajka obilnije potvrđena u jeziku frančezarija: sjestit, provestit, jestit, izjestit, pastit, upastit, dopastit, smestit, trestit. Primjeri pokazuju kako do podvostručenja dolazi u infinitiva -sti, premda su u Držićevu jeziku takvi glagoli bili neokrenjeni (-sti) i nikad podvostručeni (Rešetar 1933: 183, 184).

Zamjena likvida $l / r$ ovjerena je u imenici ‘stablo': stabra.

Umetanje vokala $a$ unutar dočetne suglasničke skupine primljenica na - $n t \mathrm{u}$ dubrovačkome je govoru česta pojava. Kolende su potvrdile samo jednu imenicu toga završetka i njezin je lik potvrdio prošireni dočetak: istromenat. Taj jedan primjer ne treba navesti na ishitreni zaključak da je riječ o navici bez iznimke oporuke su uz čestotnije primjere na -nat (45 potvrda) zasvjedočile i nekolicinu primjera na -nt (8 puta), a u frančezarijama je omjer bio nešto približniji.

Rotacizam nije potvrđen nijednim primjerom: možeš, može, možemo. Jednako je i u oporukama gdje se glagol 'moći' u 3. 1. jd. uvijek (48 puta) pojavljuje s likom 
može. Lik more već je tada pripadao prošlosti, što ne čudi jer ga i Rešetar (1952: 53) drži zastarjelim za razdoblje prije 17. stoljeća. Isto potvrđuje i Budmani (1883: 159) za jezik 19. stoljeća, a u današnje se vrijeme lik more doživljava ruralnim.

\section{Zaključno slovo}

U kolendama prevladava jekavski odrazjata. S obzirom na zaključke koje o tome imamo iz relevantne literature, tj. da se u Dubrovniku praslavenski ě odrazio vokalskim slijedom (i)je već u 13. stoljeću, jekavica je u kolendama iz 19. stoljeća očekivana. No, premda su kolende u generičkome smislu pjesme prigodnice, a Zamanjine su kolende lišene književne estetike (Obradović Mojaš 2012: 395), one ipak poštuju formalne zakonitosti svoje književne vrste pa se u njima iz istoga razloga možda može protumačiti i pojava ikavice - karakteristične za pjesnički izraz Zamanjina pretka Ivana Gundulića čije ikavizme jezikoslovci tumače kao stileme. Naime, Gundulićev pjesnički izraz, osim općejekavskim i dubrovačkim obilježjima, obiluje i ikavizmima koji ne pripadaju standardnomu jeziku. Broj ikavizama u njegovu opusu varira ovisno o temi pojedina djela, a malo je likova koji su uvijek i isključivo ikavski. Da su Gundulićevi ikavizmi stilski elementi, a ne osobni nesvjesni izbor koji bi ukazivao na to da je dubrovački organski idiom bio ikavski, otkrio je velik broj ijekavskih fleksijskih završetaka (upravo onih u kojima bi se ikavski odraz mogao lakše objasniti) - što ih beziznimno potvrđuju i kolende - a mnoštvo Gundulićevih ikavskih leksema tumači se činjenicom da je ikavica bila vrlo pogodna za uzvišeni pjesnički stil jer su svitlos, kripos i lipos, Rešetarovim riječima, bile uhu milije od njihovih ijekavskih inačica (Rešetar 1941: 8).

Ostali primjeri s ikavskim ostvarajem praslavenskoga vokala $\check{e}$ u kolendama najvećim dijelom pripadaju onim slučajevima koje standardni fonološki sustav traži i u ijekavskome narječju, npr. ostvaraj $i$ ispred $o<l$ (rodio, dio).

To nije slučaj s prefiksom prě > pri. Kao poznata dubrovačka značajka taj je prefiks prisutan u svim jezičnim spomenicima i iznimke su vrlo rijetke. Poznato je da se u ranijim slojevima dubrovačkoga govora miješalo prje- i pri-, dok je odraz pre- i tada bio prava iznimka. Zamanjine kolende istu pojavu beziznimno potvrđuju (priblagom, pridragom, prisvjetla, pridaj). 
U kolendama je jekavski ostvaraj najčestotniji. Odmake u ikavskome ili ekavskome smjeru čine oni slučajevi u kojima je to u okviru norme ijekavskoga narječja. Uglavnom su tomu razlog fonološke (distribucijske) ili morfološke zakonitosti i u tome se smislu dubrovački govor najčešće ne razlikuje od standardnoga jezika.

Istu je situaciju za 19. stoljeće opisao i filolog Pero Budmani (v. Budmani 1883: 156).

Opis fonološke razine jezika iz kolenda objedinjuje jezične značajke koje dubrovački govor 19. stoljeća određuju kao posebni zapadnoštokavski i jekavski govor, koji je, stoga, tek danas, dio ijekavskoga novoštokavskog dijalekta (obično zvanoga istočnohercegovačkim) jer je do danas primio niz njegovih značajka. Tako u jeziku kolenda nema znakovitih hercegovačkih ikavizama, ali ima sličnih s istočnobosanskim govorima (usp. npr. u Vijaci u Bosni) - prid i priko. ${ }^{10}$

Stoga se može reći kako se fonološki sloj jezika Zamanjinih kolenda iz 19. stoljeća bitno ne razlikuje od onoga iz dubrovačkih oporuka 17. i 18. st. ili iz dubrovačkih frančezarija iz 18. stoljeća. Osim što nemaju gromoglasnih ikavizama što su obilježili pjesnički dubrovački jezik, kolende se, u relevantnim fonološkim pojavama, ne razlikuju ni od Gundulićeva, stilski uzvišenoga, izričaja.

Među prvim razlikama uočit će se Gundulićevo bilježenje dočetnoga -l (bil, vidil), dok je njegova vokalizirana inačica u kolendama beziznimna. Nadalje, kolende potvrđuju redukciju početnih suglasnika (tice, tića, ćerca) dok Pjesnik početni suglasnik ne izuzima (kćer, pšenica, ptica). Čakavski je ostvaraj -j- u gospoja u Gundulića jedini fonološki izbor, dok su kolende, uz čakavski oblik (gospoja, gospoje), zasvjedočile i štokavski (gospođa, gospođe), no na tome se i zadržavaju te ne potvrđuju Gundulićeve likove poje, doje za 'pođe, dođe'.

Prema Milanu Rešetaru, filologu koji je temeljito i detaljno obradio najveći dio dubrovačke jezične baštine, jedini je pravi ikavski odraz prisutan u riječima s dočetnim $\check{e}$, što također nije za to doba neobično. Tako i kolende i ostali usporedni korpusi potvrđuju likove doli, gori, ovdi, no, dok je to u kolendama stalnica, u oporukama se pojavljuje i lik s jekavskim odrazom (ovdje). ${ }^{11}$ Treba naglasiti da se ekavski odraz gore i dole ne pojavljuje ni u jednome od usporednih korpusa.

\footnotetext{
10 Za primjere iz bosanskoga govora kao i za osnovna polazišta iz ovoga ulomka v. Lisac 1999.

11 Po njemu ni miješanje prefiksa prě- i pri-nije pravi ikavizam jer se inače ne bi samo kod prefiksa prěpojavljivao ikavski odraz (Rešetar 1952: 15).
} 
Ekavski je ostvaraj vokala ě uglavnom očekivan, odnosno podudara se s onim slučajevima koji postoje i u standardnome jeziku. To je odraz kratkoga $\check{e}$ iza $r$ u suglasničkome skupu, gdje i u standardu postoje dvojni oblici s elje: kreposti, sreće.

Za stvarno stanje dubrovačkoga govora po pitanju jata najvažniji je njegov odraz u gramatičkim morfemima (drugijem, dubrovačkijeh), a ondje se $\breve{e}$ ostvarilo isključivo i beziznimno ijekavskim odrazom. Kako je ijekavizam u gramatičkim morfemima opći pokazatelj ijekavizma, primjeri iz kolenda još jednom svjedoče o čistome ijekavskom usmjerenju dubrovačkoga idioma.

\section{Literatura:}

Budmani, Pero. 1883. Dubrovački dijalekat, kako se sada govori. Rad JAZU. 154-179.

DeAnović, Mirko. 1972. Dubrovačke preradbe Molièreovih komedija: knjiga I. JAZU. Zagreb.

Lisac, Josip. 1999. Dubrovnik i hrvatska tradicija. Vijenac 148.

Lovrić Jović, Ivana. 2014. O starome dubrovačkom govoru nazbilj. Jezična analiza dubrovačkih frančezarija. Institut za hrvatski jezik i jezikoslovlje. Zagreb.

Lovrić Jović, Ivana. 2015. Ja, Krsto Lučin Dubrovčanin, činim ovi testamenat. Jezična analiza dubrovačkih oporuka iz 17. i 18. stoljeća s transkripcijom i rječnikom. Institut za hrvatski jezik i jezikoslovlje. Zagreb.

Obradović Mojaš, Jelena. 2012. Kolende Mata Zamagne. Anali Dubrovnik 51/2. 389 460.

Obradović Mojaš, Jelena. 2017. Kolenda u Dubrovniku. Tradicija kolendavanja od 13. do 21. stoljeća. Zavod za povijesne znanosti u Dubrovniku. HAZU. Dubrovnik.

ReŠEtar, Milan. 1933. Jezik Marina Držića. Rad JAZU 248. 99-240.

ReŠEtar, Milan. 1936. Jezik pjesama Ranjinina zbornika. Rad JAZU 255. 77-220.

ReŠEtar, Milan. 1941. Glavne osobine Gundulićeva jezika. Rad JAZU 272. 1-44.

ReŠEtar, Milan. 1951. Najstariji dubrovački govor. Glas SANU 201. 1-47.

ReŠEtar, Milan. 1952. Najstarija dubrovačka proza. SAN. Beograd. 


\section{Caratteristiche fonologiche della lingua dei canti natalizi dall'inizio dell'ottocento}

\section{Riassunto}

L'articolo analizza le caratteristiche fonologiche della lingua dei canti natalizi (a Dubrovnik chiamati colende), dagli inizi dell'ottocento. Il loro autore è Matteo Zamagna (1800-1870), nobile raguseo e discendente di Giovanni Gondola. I canti furono composti da Zamagna, diciasettenne giocoso e completamente libero dal peso delle proprie origini della famiglia di illustri ragusei, specialmente nel campo di letteratura, perciò vi era quasi scontata la presenza degli elementi di un linguaggio colloquiale, composti all'interno di una cornice di formalità metrica. Siccome la parlata ragusea viene osservata nel contesto dell'idioma di Dubrovnik nel tempo e in varie specie letterarie e non letterarie, le caratteristiche fonologiche sono descritte dall'analisi comparativa, dunque, confrontano i risultati delle ricerche linguistiche dei testamenti di Dubrovnik (XVII e XVIII sec.), delle francesarie (XVIII sec.) e della lingua di Giovanni Gondola (XVII sec.).

Ključne riječi: dubrovački govor, fonološke značajke, kolende, 19. stoljeće, komparativna metoda.

Parole chiave: il dialetto di Dubrovnik, analisi fonologica, canti natalizi, l'ottocento, metodo comparativo. 